\title{
Pensononowoor
}

2015, vol. 74, 135-142

http://dx.doi.org/10.12657/denbio.074.013

Dietrich Ewald, Gisela Naujoks

\section{Vegetative propagation of wavy grain Acer pseudoplatanus and confirmation of wavy grain in wood of vegetatively propagated trees: a first evaluation}

Received: 19 December 2014; Accepted: 12 May 2015

\begin{abstract}
Over the last 15 years, shoot material from wavy grain sycamore maples (Acer pseudoplatanus L.) was collected from crowns of trees which were harvested and the stems then sold for very high values. Starting with grafts from this material, cutting propagation was tested and a tissue culture method was elaborated. However, the question of whether the wavy grain structure is expressed after vegetative propagation still remained unsolved. Recently, one of the oldest cuttings (11 years) and two grafts (17 years) were cut to look for structures of wavy grain expression. Veneer was produced from the log of the cutting-derived tree. Staining experiments were carried out using veneer sheets to improve the appearance of the structures. Based on these experiments, and in using morphological comparisons with veneer from adult wavy grain sycamore, we present the first evidence for the appearance of undulating fibre structures and the beginnings of wavy grain formation even in material at around ten years of age. A hypothesis related to the formation of wavy grain in deciduous trees is discussed.
\end{abstract}

Additional key words: figured wood, cutting, grafting, tissue culture, micropropagation

Address: D. Ewald, G. Naujoks, Thünen-Institute of Forest Genetics, Eberswalder Chaussee 3a, 15377 Waldsieversdorf, Germany, e-mail: dietrich.ewald@ti.bund.de

\section{Introduction}

Wavy grain sycamore maple is a highly valuable wood. It is used mainly for musical instruments as well as for veneer. Figured wood in general, and especially wavy grain, is observed in many species of deciduous trees, e.g. teak and walnut. The wavy grain becomes visible after splitting the wood (see Fig. 5. The reasons for the formation of such a wood structure are still unknown. There is a continuous inter- est in the true-to-type propagation of such a material because it is scarce in natural populations (a few percent of trees; Conrad 1977, 1988). In some cases, vegetative propagation by cuttings or by grafting did not give reliable results concerning the evidence for a transfer of this wood quality by any kind of vegetative propagation (e.g. black walnut - Woeste, personal communication 2013). The manifestation of such unusual wood quality may require seven to ten years, as Ewald et al. (1997) noticed in suc- 
cessful attempts to propagate curly birch clones by tissue culture. Other wood qualities like wavy grain are expressed even later (Hejnowicz and Romberger 1973). In the most valuable wavy grain logs, at an age of about $80-140$ years, the fibre waves were visible along the whole stem and in a very regular, fine structure. These logs were often sold for very high prices at public auction sales. Grafting of material from such trees (heterovegetative propagation) is possible for geneconservation or for seed orchard purposes, however, growth form and growth velocity of grafted plants are not comparable to seedlings. Therefore, the method is not useful for log production (Braun, personal communication 2012). Autovegetative cutting propagation is influenced by age and genotype of the donor tree. Tissue culture methods offer the possibility to rejuvenate and multiply such material simultaneously. This could be a starting point for the other vegetative propagation techniques afterwards, as it was shown for ash trees for example (Douglas and Pliura 2013).

In the present study, possibilities for the vegetative propagation of such valuable sycamore maple trees were examined and chances for confirmation of wood structure were proven.

\section{Material and Methods}

\section{Plant material}

There was a special interest in sycamore maples with high quality timber characterized by numerous stripes per inch of wood, which were sold at public auction sales for very high prices. Normally, a limited amount of useful branches from the crown is still available in the stand because there is a time gap between the cutting of the logs (November to December) and selling them (February to March). When quality and price were known, the forest administrations were contacted to get branches from the crown, where possible. The influence of weather (low temperature, snow $=$ favourable storage conditions in the forest) and the following fungi attack, as well as the influence of browsing activity by animals on the availability and quality of shoot buds were

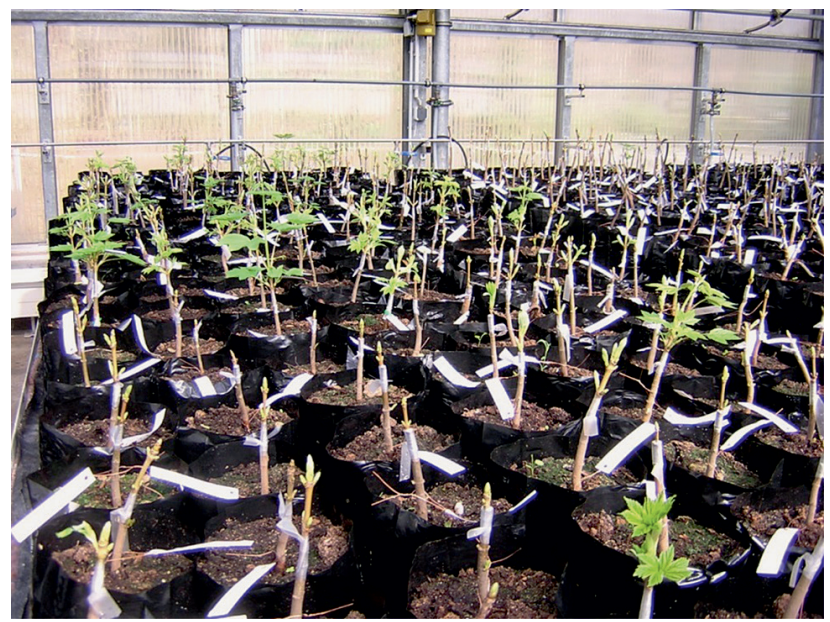

Fig. 1. Grafts of clone Leverkusen onto the micropropagated juvenile sycamore rootstock E87

also considered. The donor trees, which were used for the different experiments in the present study, are described in Table 1. In only a few cases, it was possible to get information about the age of the tree.

\section{Grafting}

Two-year-old plants from one micropropagated juvenile clone and sycamore maple seedlings of the same age were used as rootstocks for grafting parts of the selected material in March in a greenhouse (Fig. $1)$. Branches from the crown were stored at $5^{\circ} \mathrm{C}$ until the rootstock was at the right physiological stage for grafting. The grafting procedure was carried out at the Lürssen nursery at Tempelberg (Brandenburg, Germany). Some sprouting parts of the grafts (e.g. flowers) were also used to establish tissue cultures.

\section{Cutting propagation}

Although material from grafts was used, the amount of branches for that purpose was limited. That's why there was not enough material for all variants available in 2003 and 2004.

Experiment 2003: Cuttings, approximately 20 $\mathrm{cm}$ long, with two pairs of leaves each or at least with buds, were prepared from sprouted and lignified shoots (one-year-old) of grafts at the end of June/ beginning of July. Leaves on cuttings were trimmed. The cutting base was treated with rooting paste con-

Table 1. Selected wavy grain sycamore clones

\begin{tabular}{llc}
\hline \multicolumn{1}{c}{ Clone } & \multicolumn{1}{c}{ Origin, year of donor tree selection } & Approximate price fetched \\
\hline Göttingen3 & Forest office Göttingen, 1996 Age of the tree & not yet cut \\
Grimma & Wermsdorf, 2001, log bought by a violin maker & unknown \\
Mühlhausen & Mühlhausen, 2001 & unknown \\
Kempten & Forest office Kempten, 2001 & $\sim 2.070 €$ \\
Eppingen & Forest office Bietigheim, 2003 & $28.000 €$ \\
Leverkusen & Forest office Bergisch-Gladbach, 2005 & $17.000 €$ \\
Paderborn & Forest office Steinbeke, 2005 & $1.660 €$ \\
Arnstein & Forestry enterprise Arnstein, 2011 & $45.000 €$ \\
\hline
\end{tabular}


taining $9.85 \mathrm{mM}$ indole butyric acid (IBA) and $0.2 \%$ Euparen as a fungicide. Cuttings were placed in tray containers $(56 \times 18 \times 9 \mathrm{~cm}=9.0721$ volume $)$ with sand under high air humidity conditions in a greenhouse until roots were formed.

Three positions of the cuttings were tested:

1. The top of the branch $(20 \mathrm{~cm})$

2. The part behind the top $(20 \mathrm{~cm})$

3. The part after the latter $(20 \mathrm{~cm})$

The grafts derived from the crown of trees which were detected as wavy grain and sold in 2001 (clones Grimma, Mühlhausen, Kempten). Although the material was grafted on a larger scale to get sufficient cuttings later on, it was not possible to get equal numbers from all three branch positions. The evaluation of rooting success was done in October and the plants were transferred to containers.

Experiment 2004: Material from the same clones as in 2003 was used for testing the following variants including root stimulating compounds:

Var. 1: commercial substrate (Klasmann-Deilmann $\mathrm{GmbH}$, Geeste, Germany) for cutting propagation + RHIZOPON AA 2\% (commercial rooting powder)

Var. 2: commercial substrate for cutting propagation mixed with sand 1:1 + RHIZOPON AA $2 \%$

Var. 3: commercial substrate for cutting propagation+ rooting paste containing $9.85 \mathrm{mM}$ IBA (based on talkum powder)

Var. 4: sand + rooting paste of Var. 3

Var. 5: sand + treatment with Agrobacterium rhizogenes (A.rh.) strain 15834 (rooter) $+100 \mu \mathrm{M}$ acetosyringone for 24 hours

Var. 6: sand + treatment with A.rh. strain DSM 30148 (rooter) $+100 \mu \mathrm{M}$ acetosyringone for 24 hours

The experiment was started on July $6^{\text {th }} 2004$ and rooted cuttings were counted on August 24 ${ }^{\text {th }}$. Rooted plants were potted and survival was assessed four weeks later.

\section{Tissue culture}

\section{Clone establishment and shoot multiplication in vitro}

Closed or sprouting vegetative buds from grafts (clone Kempten) or removed sprouting flower parts (clone Eppingen) were used at the beginning of micropropagation experiments. Later on, flower buds from the crown of cut trees were preferred (clone Arnstein). Flower buds contain a pair of leaves at the base which have undergone the rejuvenating process during flower formation of the mature tree.

Buds were surface-disinfected for 10 minutes with $0.25 \%$ mercury chloride + one drop Tween 80 , followed by three rinses with sterile water. Afterwards, the bud scales were removed under a stereozoom mi- croscope. The remaining inner part of the bud with adhering leaves and a basal part were placed onto nutrient media. The cultures were kept at $23^{\circ} \mathrm{C}$ in a light/darkness regime of 16/8 hours with warm-

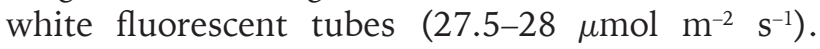
Shoots were subcultured every four weeks. Due to the limited number of available buds, no systematic, but only empirical testing of nutrient media and growth regulators was possible. Using this approach, the authors could base on long-term experiences with tissue culture of one juvenile sycamore maple clone (E87) and of other broadleaved trees (e.g. birch, oak, beech, alder).

The maple clone E87 derived from a zygotic embryo which was tested in former experiments on somatic embryogenesis. This juvenile clone is characterized by a high shoot elongation capability and has been cultivated for several years in vitro on double-strength Woody Plant Medium (WPM, Lloyd and McCown 1980) supplemented with $0.136 \mu \mathrm{M}$ thidiazuron (TDZ).

For the adult material, nutrient media used for shoot multiplication were enriched with $75 \mathrm{mg} \cdot \mathrm{l}^{-1}$ nanosilver (150 $\mu \mathrm{m}$ particles, sold by NTbase, Korea).

\section{Rooting of shoots in vitro and transplanting}

Shoots with an axis longer than $1 \mathrm{~cm}$ were harvested and placed onto the rooting medium. Shoots of the juvenile clone E87 were rooted on half-concentrated WPM supplemented with $0.27 \mu \mathrm{M}$ naphthalene acetic acid (NAA) and $0.49 \mu \mathrm{M}$ IBA. For shoots of the adult clones, a pulse induction on half-concentrated WPM with $245 \mu \mathrm{M}$ IBA for one week, followed by a transfer to hormone-free WPM, was tested alternatively.

When the root formation started after 14-21 days, plantlets were transferred to the soil under fog irrigation. Plants were adapted with gradual reduction of air humidity and were transplanted to the nursery outside after the end of the frost period resp. at the beginning of shoot growth in May.

The plantlets of the juvenile clone E87 were used as rootstock to graft the adult material from selected trees or as control to plants from wavy grain sycamore maple clones in field trials.

\section{Investigation of the wood structure}

The first cutting-derived tree of a valuable donor tree (Grimma) was eleven years old in 2013. This tree was cut the same year in October and log segments ( $1 \mathrm{~m}$ long) were produced. The basic log was cut lengthwise into halves. Veneer sheets $(0.6 \mathrm{~mm})$ were cut from one half in the Furnierwerk Prignitz (Brandenburg, Germany).

Some older grafts, which were used in 2003 and 2004 for the harvest of cuttings, are now 12 years old 
(Grimma, Kempten). Another graft (Göttingen 3) is 17 years old. All these grafts were cut and their stem basis $(80 \mathrm{~cm} \log )$ above the grafting unit was cut into halves.

Surfaces of veneer sheets and log halves were treated with tools to make them as plane and smooth as possible. Final treatment with sandpaper different in grain size improved the surface quality. Veneer sheets and log halves were treated with ammonia-saturated air or potassium hydroxide solution to get a staining of structures (Michaelsen and Buchholz 2006). After this staining and drying, a wax and oil combination (Holzwachs "CLOU", A. Clouth Lackfabrik GmbH, Offenbach, Germany) was used several times to get a better appearance of the beginning formation of undulating fibres in the wood. A veneer sheet of an older wavy grain sycamore maple tree was stained and surface-treated for comparison.

\section{Results and discussion}

\section{Vegetative propagation}

\section{Grafting}

The success of grafting the material from five adult wavy grain sycamore maples is presented in Table 2 and Figure 1. These results confirm the reports of other researchers that grafting is a reliable method to save the plant material from outstanding selected and felled trees.

Some of these grafts were reported to show a reduction in growth velocity during 10-15 years compared with seedlings on two field trials at the location Schönfelde in Brandenburg (Schneck, personal communication) and in Saxony (Braun, personal communication). The seed set, however, occurred earlier than in the juvenile material of clone E87.
By regular cutting of grafted stock plants as we did in 2003 and 2004, a partial rejuvenation is expected as it was observed for other tree species after hedging as well (Douglas 2001; Mason et al. 2002). This is a possibility to gain grafting material later on which can show a fast growth performance, comparable to seedlings.

\section{Cutting propagation}

Several publications reported about the successful cutting propagation of sycamore maple (Rohr and Hanus 1987; Ewald and Naujoks 2005). The results of different authors showed that it is possible to root cuttings, however the rooting success seems to depend on the genotype and on the age of the material used. The results of cutting propagation in 2003 are depicted in Table 3. It is obvious that the terminal position gives the best rooting percentage.

Results of the cutting propagation in 2004 are shown in Table 4. Cutting propagation from material harvested directly from the crown of selected old trees was not successful (data not shown), whereas cutting propagation after grafting was possible to a certain extent. The use of stump sprouts from the original felled trees for cutting propagation could not be tested yet. As it became clear from the results in Table 4, not all rooted cuttings could be transferred into soil successfully.

The following conclusions can be drawn from the experiments:

- treatment with Agrobacterium rhizogenes strains was not successful in comparison to other authors (Chen et al. 2003)

- auxin (2\%) was stimulating compared with variants without exogenous auxin

- a commercial rooting substrate for cutting propagation was positive

Table 2. Grafting of crown shoots from five mature sycamore trees with wavy grain

\begin{tabular}{lcccl}
\hline $\begin{array}{c}\text { Clone/year of estab- } \\
\text { lishing }\end{array}$ & $\begin{array}{c}\text { Total number of } \\
\text { grafts }\end{array}$ & $\begin{array}{c}\text { Number of vital } \\
\text { grafts }\end{array}$ & $\begin{array}{c}\text { Percentage of vital grafts } \\
\text { (\%) }\end{array}$ & \multicolumn{1}{c}{ Rootstock } \\
\hline Grimma/2001 & 249 & 145 & 58.2 & 2-year-old seedlings \\
Mühlhausen/2001 & 256 & 103 & 40.2 & 2-year-old seedlings \\
Kempten/2001 & 259 & 47 & 18.2 & $\begin{array}{l}\text { 2-year-old seedlings } \\
\text { clone E87 from micropropaga- } \\
\text { tion, 2 years }\end{array}$ \\
Leverkusen/2005 & 100 & 15 & 15 & 2-year-old seedlings \\
Paderborn/2005 & 66 & 24 & 36.4 & \\
\hline
\end{tabular}

Table 3. Rooting of cuttings from three branch positions, collected from grafted plants of three selected clones with wavy grain (Experiment 2003)

\begin{tabular}{|c|c|c|c|c|c|c|c|c|c|}
\hline \multirow[b]{2}{*}{ Clone (total No. of cuttings used) } & \multicolumn{3}{|c|}{ Position 1} & \multicolumn{3}{|c|}{ Position 2} & \multicolumn{3}{|c|}{ Position 3} \\
\hline & $\begin{array}{l}\text { Total No. } \\
\text { of cuttings }\end{array}$ & $\begin{array}{l}\text { Rooted } \\
\text { cuttings }\end{array}$ & $\%$ & $\begin{array}{l}\text { Total No. } \\
\text { of cuttings }\end{array}$ & $\begin{array}{l}\text { Rooted } \\
\text { cuttings }\end{array}$ & $\%$ & $\begin{array}{l}\text { Total No. } \\
\text { of cuttings }\end{array}$ & $\begin{array}{l}\text { Rooted } \\
\text { cuttings }\end{array}$ & $\%$ \\
\hline Grimma (509) & 210 & 12 & 5.7 & 125 & 0 & 0 & 174 & 0 & 0 \\
\hline Mühlhausen(138) & 58 & 4 & 6.8 & 32 & 0 & 0 & 48 & 1 & 2.0 \\
\hline Kempten (158) & 70 & 2 & 2.8 & 29 & 0 & 0 & 59 & 0 & 0 \\
\hline
\end{tabular}


Vegetative propagation of wavy grain Acer pseudoplatanus and confirmation of wavy grain in wood... 139

Table 4. Influence of treatment and substrate on rooting success after 6 weeks and survival in the soil (Var. 1 commercial substrate for cutting propagation + RHIZOPON AA 2\%, Var. 2 commercial substrate mixed with sand 1:1 + RHIZOPON AA 2\%, Var. 3 commercial substrate + rooting paste, Var. 4 sand + paste, Var. 5 sand + A. rh. 15834, Var. 6 sand + A. rh. DSM 30148)

\begin{tabular}{|c|c|c|c|c|c|c|c|c|c|}
\hline \multirow[t]{2}{*}{ Variant } & \multicolumn{3}{|c|}{ Grimma $(\mathrm{N}=279)$} & \multicolumn{3}{|c|}{ Mühlhausen $(\mathrm{N}=127)$} & \multicolumn{3}{|c|}{ Kempten $(\mathrm{N}=177)$} \\
\hline & Rooted/total N & Potted & Survival \% & Rooted/total N & Potted & Survival \% & Rooted/total N & Potted & Survival \% \\
\hline 1 & $22 / 135$ & 12 & 8.88 & $11 / 36$ & 6 & 16.66 & $1 / 48$ & 0 & 0 \\
\hline 2 & $5 / 48$ & 3 & 6.25 & $7 / 11$ & 5 & 45.45 & $0 / 12$ & 0 & 0 \\
\hline 3 & $14 / 48$ & 10 & 20.83 & - & - & - & $7 / 11$ & 1 & 9.0 \\
\hline 4 & $8 / 48$ & 5 & 10.41 & - & - & - & $0 / 12$ & 0 & 0 \\
\hline 5 & - & - & & $1 / 40$ & 1 & 2.5 & $18 / 51$ & 0 & 0 \\
\hline 6 & - & - & & $0 / 40$ & 0 & 0 & $22 / 40$ & 0 & 0 \\
\hline
\end{tabular}

- there is a high clonal dependence of rooting success

\section{Tissue culture}

Different maple species were tested for their tissue culture ability as Ďurkovič and Mišalová (2008) reported in their comprehensive review. Successful attempts to micropropagate wavy grain sycamore maple from selected trees in the field were also already described (Gebhardt and Bohnens 2005). The expression of the expected wood quality (wavy grain), however, was not yet proved after several years.

The method presented here was optimized according to the available plant material which could be used in limited amounts only. The main problem in sycamore maple tissue cultures is the existence of endophytic bacteria. In the beginning of culture establishing, the explants appear clean. With an increasing number of subcultures endophytic bacteria appear, especially when the cultures are under stress (temperature, too long subculture intervals, etc.).

After approximately half a year, the first shoots developed in vitro (Fig. 2). An advantage of tissue culture over longer time periods (years) is the partial rejuvenation of adult material. This was visible as the number of shoots formed increased and more and more shoots elongated. The process can drag on

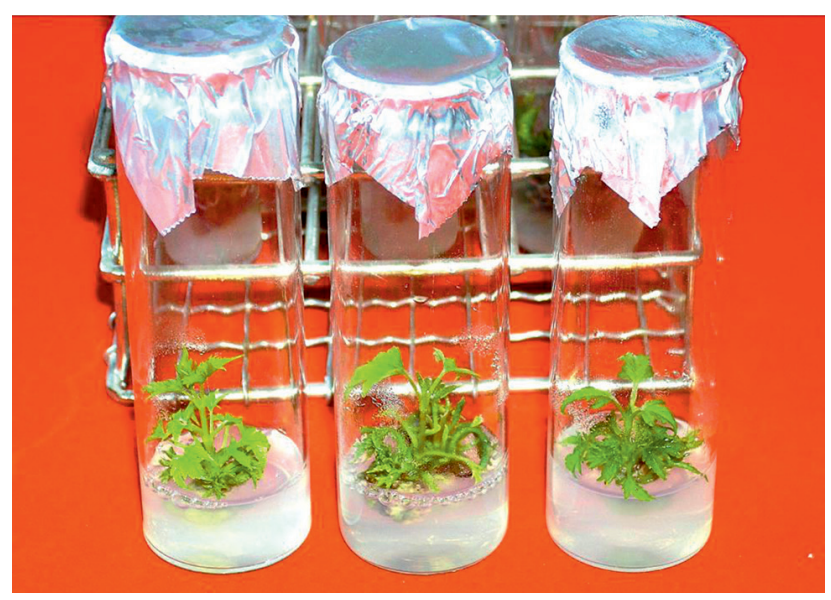

Fig. 2. Tissue culture of a selected wavy grain sycamore maple (clone Kempten) for months or years and it is difficult to prove it with suitable experiments. The phenomenon, however, is well known and was observed by several authors (Giri et al. 2004).

Following the method described here and using the media suggestions presented in Table 5, it was possible to propagate six out of eight selected sycamore maple trees in vitro. Acclimatization was successful with $>70 \%$ survival. After transfer of tissue culture plants to the nursery, it became obvious that this material grows similarly to a seedling derived clone (E87). The first field test with three clones was established in 2013.

Table 5. Nutrient media and growth regulators used for the micropropagation of sycamore maple

\begin{tabular}{ll}
\hline $\begin{array}{c}\text { Multiplication medium } \\
\text { (alternating monthly) }\end{array}$ & \multicolumn{1}{c}{ Rooting medium } \\
\hline Double-strength WPM + & Half-strength WPM + 0.27 $\mu \mathrm{M}$ \\
$0.136 \mu \mathrm{M}$ TDZ & NAA + 0.49 $\mu \mathrm{M}$ IBA \\
Full-strength WPM $+7 \mu \mathrm{M}$ & Alternative: Half-strength \\
zeatin & WPM + 245 $\mu \mathrm{M}$ IBA for one \\
& week, then transfer to WPM + \\
& $0.1 \%$ activated charcoal \\
\hline
\end{tabular}

\section{Wood structure}

At the age of eleven years, the oldest cutting-derived plant was cut (Fig. 3). Veneer was produced and different staining experiments were carried out.

As a result we observed that veneer sheets showed an undulating distorted behaviour of fibres which formed first structures of wavy lines after 3-6 years as it is shown in Figure 4. In this picture, the first apparent undulating fibre bundles of the veneer from the eleven-year-old tree, the former cutting, were visible in the same way as in the regular wave structures in older logs of other wavy grain sycamore trees after splitting (washboard appearance).

Thus, even the splitting of thin veneer sheets from the log with extremely sharp tools led to undulating structures on the surface of the sheets. Single waves came above on the one side of the veneer and were negatively visible on the other side of the veneer 


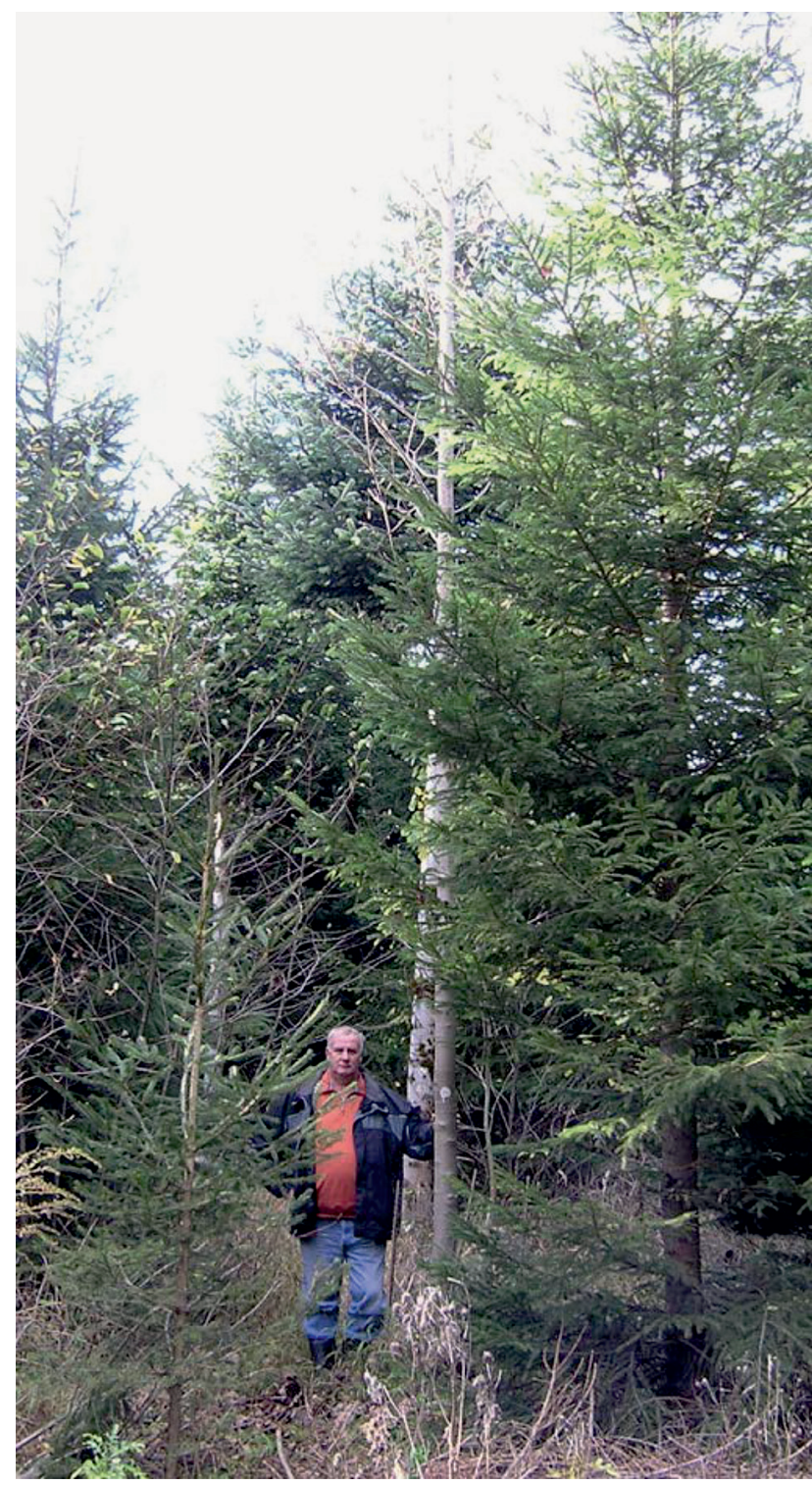

Fig. 3. Eleven-year-old plant derived from a cutting of the selected clone Grimma

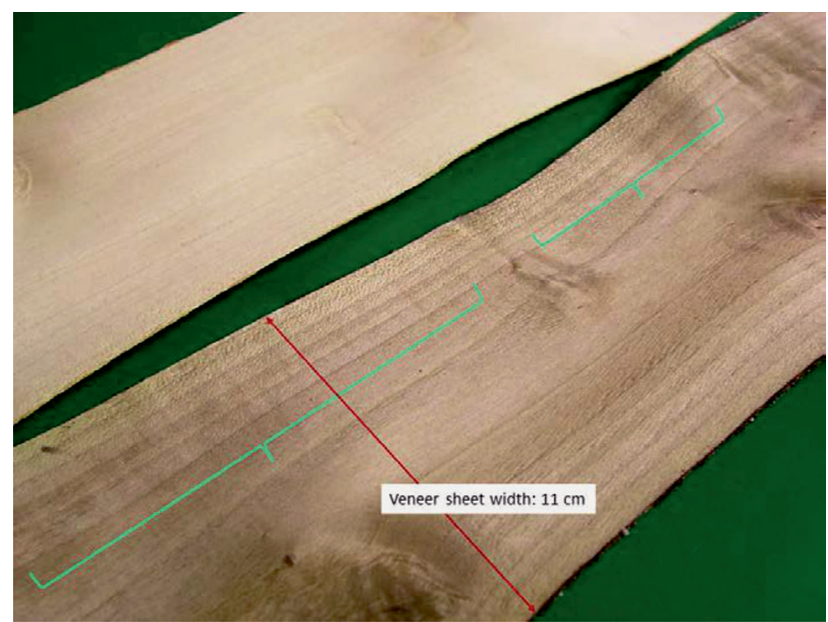

Fig. 4. Beginning formation of wavy grain structures after 3-6 years in a veneer sheet of the 11-year-old cutting plant (clone Grimma)

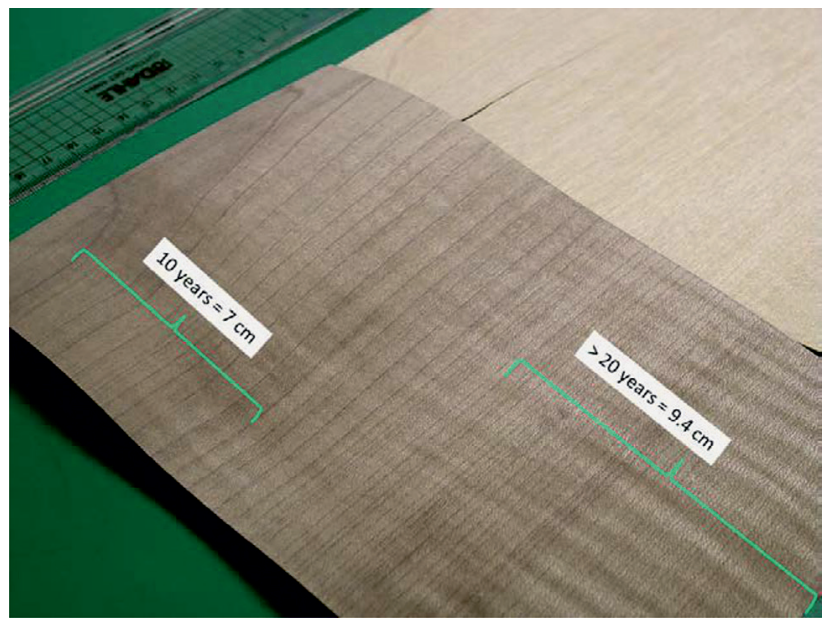

Fig. 5. Veneer from a selected adult wavy grain sycamore clone (wavy grain structures are already evident after 5-10 years although the perfect formation of waves is visible after approximately 20 years)

sheet, yet in a small and beginning scale. The real and final formation of a clear wavefront was visible in a veneer sheet of an adult sycamore tree after 20-30 years (Fig. 5) which was used for comparison. Hejnowicz and Romberger (1973) showed that in ash for example, the waves were not apparent before 10 years. This was recently confirmed by Sopushynskyy and Teischinger (2013).

Such a wavy grain formation can be observed in a minor number of trees within a population in almost all deciduous trees. The still unsolved question is: what is the reason for such an abnormal grain structure? In some cases, the wood reacts to exogenous stresses like wind with the formation of wavy-grainlike fibres and structures on one side of the tree. If one is looking for similar events in trees, he will find such waves where reaction wood is formed, e.g. on the bottom side of branches or on the inside of bending stems, e.g. in Salix matsudana "Tortuosa".

Some deciduous trees form such wavy grain structures on the stem bases, too. Thus, such reaction wood is formed on the side of the affected part of the plant. The origin of these fibre structures is not yet known. It is sure that phytohormones like auxin and ethylene are involved in the process of reaction wood formation (Nelson and Hillis 1978; Pilate et al. 2004).

Therefore it seems to be justified, related to the above mentioned phenomenon of reaction wood formation in certain areas of a deciduous tree, that wavy grain formation in a whole tree can be hypothetically discussed as a general mutation in the process of growth regulation leading to a permanent reaction wood formation, without disturbing normal growth velocity.

The results of grafts from wavy grain individuals on the normal rootstock were not always clear 
and predictable concerning the expression of wavy structures. We have no final evidence that in all cases where grafts were produced, a final wavy grain structure has also been formed. This may have two causes. On the one hand, a lot of patience is needed because it takes at least ten years to see a beginning of this process, or 20-30 years to its full manifestation. On the other hand, the phytohormone balance of the material might have changed initiated by the grafting event, this means via an additional respectively altered phytohormone influence of the rootstock.

Provided that a new rootstock can lead to another phytohormone balance of the whole tree, an expression of wavy grain structures is not necessarily to be expected, because the relation in phytohormone balance has changed.

Ďurkovič et al. (2015) recently reported about investigations on numerous traits of cell wall composition and wood anatomy in micropropagated and grafted plants of the Dutch elm hybrid 'Dodoens'. Related to disease resistance traits, the authors would not favour one of the two propagation types. On the other hand, they reported about higher lignin content in grafts, what might influence the mechanical and physical properties of cell walls. A possible contribution of the rootstock to the cell wall compounds was mentioned too. These results encourage the authors of the present paper to continue preservation measures of wavy grain sycamore via grafting on plants from one micropropagated juvenile clone (E87) to avoid effects of many different rootstocks. However, a possible influence of clone E87, used as rootstock, on later wavy grain formation has to be tested.

In his publication, Conrad (1977) presented one of the first pictures of a graft union of wavy grain sycamore maple with an ordinary maple. It is not obvious on the photo if the grafted part was the wavy grain individual or if a normal sycamore maple was grafted by chance onto a wavy grain maple rootstock. The author himself was not sure about this. This hypothesis of changed phytohormone balance or metabolism in general as the origin of wavy grain formation is intended to be tested in a planned research project in Germany which will be aimed at vegetative propagation and search for markers of wavy grain formation in sycamore maple.

From the above mentioned results, we can conclude that wavy grain appearance in vegetatively cutting-propagated sycamore maple material is confirmed and is visible after at least ten years. It is expected that micropropagated plants will show the same results (true-to-type-propagation) as was the case for other figured woods (e.g. curly birch, Ewald et al. 1997).

\section{Acknowledgements}

The authors would like to thank all staff members of the Thuenen-Institute for Forest Genetics who supported the work on wavy grain sycamore maple for more than 20 years at the location Waldsieversdorf. The Lürssen nursery (F.-O. Lürssen Baumschulen $\mathrm{GmbH}$ \& Co. $\mathrm{KG}$ ) is kindly acknowledged for the preparation of the numerous grafts. We thank the colleagues of the Landesstelle für Forstliches Vermehrungsgut Waldsieversdorf for keeping the sycamore maple grafts on their nursery area. Many thanks to the Furnierwerk Prignitz for producing the veneer sample. We are grateful to Dr. Gerald Koch (Thünen-Institute of Wood Research) who provided the veneer of an adult wavy grain sycamore maple.

\section{References}

Chen K.P., Ho C.K., Kuo S.R. 2003. Enhancement of Agrobacterium rhizogenes on root formation of Taxus mairei cuttings of mature trees. Taiwan Journal of Forest Science 18: 213-223.

Conrad J. 1977. Ein Indiz für die Vererbbarkeit gewisser Holzstrukturen. Forst und Holzwirt 32: 217-218.

Conrad J. 1988. Seltene abnorme Holzstrukturen und -farben bei Laubhölzern. Die Holzzucht 42: 1-9.

Douglas G. 2001. Vegetative propagation of selected reproductive stocks of ash and sycamore. In: Vegetative propagation techniques for oak, ash, sycamore and spruce. Thompson D., Harrington F., Douglas G.C.,Hennerty M.J., Nakhshab N., Long R. (eds.). COFORD, Dublin, pp. 16-28.

Douglas G.C., Pliura A. 2013. Common ash (Fraxinus excelsior L.) - Vegetative propagation and cryopreservation. In: Forest Tree Breeding in Europe. Pâques L.E. (ed.). Springer.

Ďurkovič J., Mišalová A. 2008. Micropropagation of Temperate Noble Hardwoods: An Overview. Functional Plant Science and Biotechnology 2: 1-19.

Ďurkovič J., Kačík F., Mamoňová M., Kardošová M., Longauer R., Krajňáková J. 2015. The Effects of Propagation Techniques on Cell Wall Chemistry and Wood Anatomy in Micropropagated and Grafted Plants of the Dutch Elm Hybrid 'Dodoens'. Journal of the American Society for Horticultural Science 140: 3-11.

Ewald D., Naujoks G., Kohlstock N., Frühwald A. 1997. Braunmaserbirke aus dem Pflanzgarten. Wie lang ist der Weg von der Gewebekultur zum Furnier? (Brown curly-birch. How long is the road from tissue culture to veneer?). Furnier-Magazin 12: 66-69. 
Ewald D., Naujoks G. 2005. Untersuchungen zur vegetativen Vermehrung von Riegelahorn. Nachrichten der Bundesforschungsanstalt für Forstund Holzwirtschaft, Heft 3.

Gebhardt K., Bohnens J. 2005. Mikrovermehrung und Klonprüfung bei Berg/Riegelahorn. Tagungsband der 26. Tagung der AG Forstgenetik und Forstpflanzenzüchtung, Fuldatal, 146-153.

Giri C.C., Shyamkumar B., Anjaneyulu C. 2004. Progress in tissue culture, genetic transformation and applications of biotechnology to trees: an overview. Trees 18: 115-135.

Hejnowicz Z., Romberger J.A. 1973. Migrating cambial domains and the origin of wavy grain in $x y-$ lem of broadleaved trees. American Journal of Botany 60: 209-222.

Lloyd G., McCown B. 1980. Commercially-feasible micropropagation of mountain laurel, Kalmia latifolia, by use of shoot-tip culture. International Plant Propagators Society, Combined Proceedings 30: 421-427.
Mason W.L., Menzies M.I., Biggin P. 2002. A comparison of hedging and repeated cutting cycles for propagating clones of Sitka spruce. Forestry 75: 149-162.

Michaelsen H., Buchholz R. 2006. Vom Färben des Holzes - Holzbeizen von der Antike bis in die Gegenwart. Michael Imhof Verlag, Petersberg.

Nelson N.D., Hillis W.E. 1978. Ethylene and tension wood formation in Eucalyptus gomphocephala. Wood Science Technology 12: 309-315.

Pilate G., Déjardin A., Laurans F., Leplé J.C. 2004. Research review: Tension wood as a model for functional genomics of wood formation. New Phytologist 164: 63-72.

Rohr R., Hanus D. 1987. Vegetative propagation of wavy grain sycamore maple. Canadian Journal of Forest Research 17: 418-420.

Sopushynskyy I., Teischinger A. 2013. Diagnostic features of Fraxinus excelsior L. with wavy-grained wood growing in Ukraine. Forest Research Papers 74: 189-195. 